\title{
Analisis Faktor Yang Berhubungan Dengan Perilaku Pelayan Rumah Makan Dalam Pencegahan Covid-19 Di Kecamatan Telaga
}

\author{
Nanang R. Paramata, Gusti Pandi Liputo, Olvilia Abril Biki, Ahmad Rivaldi Bobihu \\ Program Studi Kedokteran Fakultas Kedokteran Universitas Negeri Gorontalo \\ Koresponden email: roswita@ung.ac.id
}

Received: 13 August 2021; Revised: 02 October 2021; Accepted: 28 December 2021

DOI: http://dx.doi.org/10.37905/aksara.8.1.609-620.2022

\begin{abstract}
ABSTRAK
Kasus corona virus atau kita kenal sebagai covid-19 ini pertama kali muncul dan menyerang masyarakat di Kota Wuhan, China. Pada awalnya Covid-19 ini diduga merupakan penyakit yang serupa dengan pneumonia, dengan gejala yang ditunjukkan berupa sakit flu. Gejala yang lain muncul diantaranya yaitu batuk, demam yaitu dimana suhu badannya diatas $36^{\circ} \mathrm{C}$, merasa letih, napas menjadi sesak, dan kurang nafsu makan. Namun pada kenyataannya berbeda dengan influenza, corona virus ini sangat berbahaya karena dapat berkembang dengan sangat cepat sehingga mengakibatkan terjadinya infeksi yang lebih parah dan kegagalan organ-organ tubuh manusia sampai pada kematian. Penelitian ini akan dilaksanakan di 13 Rumah Makan yang sudah terdaftar, bersertifikat, dan memiliki izin usaha yang ada di Kecamatan Telaga Kabupaten Gorontalo Penelitian ini dilaksanakan pada bulan Maret-April 2020. Pengetahuan pelayan rumah makan dalam pencegahan Covid-19 di Kecamatan Telaga yaitu sebanyak 27 responden (41,5\%) dalam kategori kurang, 13 responden (20\%) memiliki pengetahuan baik, 25 responden $(38,5 \%)$ cukup baik. Sikap pelayan rumah makan dalam pencegahan Covid di Kecamatan Telaga yaitu sebanyak 34 responden $(52,3 \%)$ sudah dalam kategori baik, 29 responden $(44,6 \%)$ cukup dan 2 responden $(3,1 \%)$ kurang. Perilaku pelayan rumah makan dalam pencegahan Covid-19 di Kecamatan Telaga yaitu sebanyak 34 responden $(52,3 \%)$ dalam kategori cukup baik, 9 responden $(13,8 \%)$ baik dan 22 responden (33,8\%) kurang baik.

Kata kunci: Corona Virus, Perilaku, Pencegahan Covid-19, Kabupaten Gorontalo
\end{abstract}

\section{PENDAHULUAN}

Masalah kesehatan yang saat ini menjadi sorotan seluruh dunia dan sangat penting untuk mendapatkan perhatian dari para ilmuwan kesehatan dan masyarakat umum adalah penyakit yang diakibatkan oleh corona virus. Corona Virus Disease - 19 atau yang lebih dikenal dengan istilah Covid-19 telah ditetapkan oleh WHO (World Health Organization) atau Badan Kesehatan Dunia bahwa Covid-19 sebagai Kedaruratan Kesehatan Masyarakat yang Meresahkan Dunia (KMMD) (Keliat dkk, 2020). Coronaviruses (CoV) merupakan salah satu bagian dari keluarga virus yang menyebabkan penyakit mulai dari flu sampai penyakit yang lebih berat seperti Middle East Respiratory Syndrome (MERS$\mathrm{CoV}$ ) and Severe Acute Respiratory Syndrome (SARS-CoV) (Widiyani, 2020).

AKSARA: Jurnal Ilmu Pendidikan Nonformal 
Pada tanggal 31 Desember 2019, WHO China Country Office melaporkan bahwa adanya kasus kluster pneumonia disertai penyebab yang tidak begitu jelas di Kota Wuhan, China. Kasus ini terus berkembang hingga pada 7 Januari 2020, dan akhirnya diketahui etiologi dari penyakit ini adalah salah satu jenis baru coronavirus atau yang disebut sebagai coronavirus, yaitu merupakan virus jenis baru dan virus ini sebelumnya tidak pernah diidentifikasi pada manusia (KEMENKES RI, 2020).

Kasus corona virus atau kita kenal sebagai covid-19 ini pertama kali muncul dan menyerang masyarakat di Kota Wuhan, China. Pada awalnya Covid-19 ini diduga merupakan penyakit yang serupa dengan pneumonia, dengan gejala yang ditunjukkan berupa sakit flu. Gejala yang lain muncul diantaranya yaitu batuk, demam yaitu dimana suhu badannya diatas $36^{\circ} \mathrm{C}$, merasa letih, napas menjadi sesak, dan kurang nafsu makan. Namun pada kenyataannya berbeda dengan influenza, corona virus ini sangat berbahaya karena dapat berkembang dengan sangat cepat sehingga mengakibatkan terjadinya infeksi yang lebih parah dan kegagalan organ-organ tubuh manusia sampai pada kematian. Kondisi darurat bisa terjadi pada pasien-pasien yang memiliki masalah kesehatan sebelum terserang corona virus (Mona, 2020).

Di Indonesia pada tanggal 11 Maret 2020, wabah Covid-19 ini secara resmi ditetapkan sebagai pandemi global oleh WHO, menurut perkembangannya corona virus ini terus mengalami peningkatan hingga 13 kali lipat dengan jumlah kasus yang telah dilaporkan diluar China yaitu lebih dari 2,3 juta orang di 185 negara diseluruh dunia (Mansuri dkk, 2020).

Berdasarkan data WHO, pada awal tahun 2021 bulan Januari hingga Maret kasus corona virus yang telah dilaporkan yaitu 222 negara terjangkit dan 189 negara transmisi lokal di seluruh dunia kasus yang terkonfirmasi dengan total 121,969,223 dan jumlah kematian 2,694,094 jiwa. Adapun secara Nasional terkonfirmasi data corona virus pada awal tahun 2021 bulan Januari hingga Maret di Indonesia terkonfirmasi total kasus 1,455,788 dengan jumlah kematian 39,447 jiwa (KEMENKES RI, 2021). Pandemik Covid-19 ini terus mengalami perkembangan yang sangat pesat dimulai dari akhir tahun 2019 hingga pada tahun 2021 sekarang ini. Coronaviruses (CoV) merupakan salah satu bagian dari keluarga virus yang menyebabkan penyakit mulai dari flu sampai penyakit yang lebih berat seperti Middle East Respiratory Syndrome (MERS-CoV) and Severe Acute Respiratory Syndrome (SARS-CoV) (Widiyani, 2020). Corona Virus adalah virus RNA untai positif yang beruntai tunggal yang tidak tersegmentasi, merujuk pada virus yang menyerang dan berkembang biak di sel epitel saluran pernapasan yang dapat menyebabkan gejala pernapasan dan sistemik (Zhou, 2020).

Menurut Pennington (2020), virus ini disebabkan dari hewan dan tertular ke manusia dan sekarang tersebar dari manusia satu ke manusia lainnya. Pada manusia virus ini disebabkan oleh percikan droplet dari bersin, batuk atau napas sehingga bisa menginfeksi saluran pernapasan sesorang.

Menurut Centers Disease Control (CDC, 2020), corona virus ini tersebar dari orang ke orang disebabkan karena jarak yang saling berdekatan antara satu dengan lainnya, percikan droplet dari orang yang sedang terinfeksi batuk atau bersin sehingga terhirup ke saluran pernapasan atau dengan kata lain ke dalam paru-paru, serta menyentuh permukaan atau benda yang terinfeksi. 


\section{METODE PENELITIAN}

Penelitian ini akan dilaksanakan di 13 Rumah Makan yang sudah terdaftar, bersertifikat, dan memiliki izin usaha yang ada di Kecamatan Telaga Kabupaten Gorontalo Penelitian ini akan dilaksanakan pada bulan Maret-April 2020/

Jenis penelitian yang digunakan dalam penelitian ini adalah penelitian kuantitatif, dengan desain deskriptif. Metode penelitian deskriptif ini dilakukan guna untuk mengetahui keberadaan variabel mandiri, baik hanya pada satu variabel atau lebih (variabel yang berdiri sendiri atau variabel bebas) dengan tidak membuat perbandingan variabel itu sendiri dan mencari hubungan dengan variabel lain (Sugiyono, 2017)

Variabel dalam penelitian ini adalah Pengetahuan, Sikap dan Perilaku dalam Pencegahan Covid-19.

\section{HASIL DAN PEMBAHASAN}

Berdasarkan hasil penelitian didapatkan responden dengan kategori pengetahuan kurang yakni sebanyak 27 responden $(41,5 \%)$. Hal ini dikarenakan tingkat pendidikan responden yang memiliki tingkat pendidikan Sekolah Dasar dan Sekolah Menengah Pertama yakni sebanyak 12 responden. Menurut teori Sujarwo (2012), yang menyatakan bahwa pendidikan merupakan salah satu institusi yang mana seseorang di didik, dilatih dan dibekali berbagai ilmu yang relevan dengan kehidupan manusia itu sendiri, tingkat pendidikan yang rendah akan mengakibatkan seseorang memiliki pengetahuan rendah. Hal ini sejalan dengan penelitian yang dilakukan oleh Yanti (2020) dalam hasil penelitiannya menunjukkan bahwa adanya hubungan yang erat pengetahuan dengan tingkat pendidikan. Peneliti berasumsi bahwa pendidikan atau dasar keilmuan dapat mempengaruhi pengetahuan seseorang.

Adapun responden yang memiliki tingkat pendidikan Sekolah Menengah Atas/Kejuruan tetapi dalam kategori pengetahuan kurang yakni sebanyak 15 responden. Hal ini dikarenakan ada faktor lain seperti kurangnya sumber informasi di lingkungan pekerjaan dan dibuktikan dengan hasil pengamatan peneliti di seluruh rumah makan yaitu tempat yang dijadikan lokasi penelitian didapatkan tidak terpasang informasi-informasi tentang corona virus serta hasil wawancara yang dilakukan peneliti dengan responden didapatkan responden menyatakan bahwa mereka kurang dalam membaca tentang corona virus karena kesibukan di tempat kerja dan ketika lelah mereka lebih memilih istirahat dibandingkan mencari informasi tentang corona virus.

Menurut Teori Fahmi (2012), yang menyatakan sumber informasi merupakan salah satu faktor yang mempengaruhi tingkat pengetahuan seseorang. Semakin rendahnya informasi-informasi yang didapatkan oleh seseorang maka seseorang tersebut akan mengalami keterbelakangan dalam kehidupannya, kekurangan ide, kekurangan berpikir dan kurang pengetahuan. Hal ini sejalan dengan penelitian yang dilakukan oleh Amelia (2020) dalam hasil penelitiannya yang menunjukkan sebagian besar pelayan rumah makan belum memiliki pengetahuan yang baik, hal ini dikarenakan sebagian besar rumah makan yang menjadi tempat penelitian belum terdapat serta terpasang informasiinformasi dan imbauan kesehatan tentang corona virus. Peneliti berasumsi rendahnya informasi-informasi yang diperoleh akan berpengaruh pada pengetahuan seseorang.

Berdasarkan hasil penelitian ini juga didapatkan tingkat pengetahuan responden masih dalam kategori cukup baik yakni sebanyak 25 responden $(38,5 \%)$. Hal ini dikarenakan sebagian besar responden berusia lebih dari 26 tahun yakni sebanyak 20

AKSARA: Jurnal Ilmu Pendidikan Nonformal 
responden. Menurut teori Maulana (2007), yang menyatakan bahwa usia merupakan umur individu yang terhitung saat dilahirkan sampai berulang tahun. Rentang usia lebih dari 26 tahun merupakan usia yang sudah termasuk dalam masa dewasa awal. Ada beberapa faktor fisik yang dapat menghamat proses belajar pada orang dewasa diantaranya gangguan penglihatan dan pendengaran sehingga membuat penurunan pada suatu waktu dalam kekuatan berfikir dan bekerja . Hal ini sejalan dengan penelitian yang dilakukan oleh Prihati (2020) dalam hasil penelitiannya menunjukkan bahwa adanya hubungan yang signifikan antara usia dengan pengetahuan masyarakat di Kelurahan Baru Kotawaringin Barat tentang corona virus. Peneliti berasumsi bahwa usia dapat mempengaruhi tingkat pengetahuan seseorang.

Adapun responden yang berusia kurang dari 26 tahun tetapi masih dalam kategori pengetahuan cukup baik yakni sebanyak 5 responden, ini dikarenakan responden memiliki tingkat pendidikan yang rendah. Menurut teori Sarwono \& Meinarno (2011), yang menyatakan bahwa seseorang yang memiliki tingkat pendidikan yang rendah relative sulit menerima sesuatu hal yang baru. Hal ini sejalan dengan penelitian yang dilakukan oleh Sukesih (2021) dalam hasil penelitiannya menunjukkan bahwa adanya hubungan antara tingkat pendidikan dengan pengetahuan. Peneliti berasumsi bahwa tingkat pendidikan dapat mempengaruhi pengetahuan seseorang.

Berdasarkan hasil penelitian ini juga didapatkan tingkat pengetahuan responden dalam kategori baik yakni sebanyak 13 responden (20\%). Hal ini dikarenakan tingkat pendidikan responden sebagian besar pada tingkat Sekolah Menengah Atas/Kejuruan dan lulusan sarjana yakni sebanyak 9 responden. Menurut Teori Notoadmodjo (2012), yang menyatakan bahwa pendidikan sangat erat kaitannya dengan pengetahuan dan pengetahuan bisa didapatkan dari pendidikan, semakin tinggi seseorang menempuh pendidikan maka semakin luas dan baik pengetahuannya. Hal ini sejalan dengan penelitian yang dilakukan oleh Purnamasari (2020) dalam hasil penelitiannya menunjukkan adanya hubungan antara pengetahuan dengan tingkat pendidikan. Peneliti berasumsi bahwa tingkat pendidikan yang tinggi merupakan dasar utama untuk mendapatkan pengetahuan yang baik.

Adapun responden yang memiliki tingkat pendidikan Sekolah Dasar dan Sekolah Menengah Pertama tetapi dalam kategori pengetahuan baik yakni sebanyak 4 responden. Hal ini dikarenakan oleh pengalaman responden, berdasarkan hasil wawancara yang dilakukan peneliti dengan responden didapatkan responden menyatakan bahwa mereka pernah menghadiri dan mendapatkan edukasi kesehatan tentang corona virus di wilayah tempat tinggal mereka masing-masing dan hal ini menjadi salah satu pengalaman yang membuat mereka mengetahui tentang corona virus. Menurut teori Nursalam (2011), yang menyatakan bahwa pengalaman belajar dan mendapatkan suatu hal atau informasi dapat memberikan dan menambah pengetahuan seseorang dari tidak tahu menjadi tahu. Hal ini sejalan dengan penelitian yang dilakukan oleh Sharrif (2021) dalam hasil penelitiannya menunjukkan responden dengan tingkat pengetahuan yang baik rata-rata mendapatkan informasi dan edukasi kesehatan. Peneliti berasumsi bahwa pengalaman mendapatkan edukasi kesehatan dapat mempengaruhi pengetahuan seseorang. 
AKSARA: Jurnal Ilmu Pendidikan Nonformal

P-ISSN 2407-8018 E-ISSN 2721-7310 DOI prefix $\underline{10.37905}$

Volume 08, (1), January 2022

http://ejurnal.pps.ung.ac.id/index.php/Aksara

\section{a. Sikap Pelayan Rumah Makan Dalam Pencegahan Covid-19 di Kecamatan Telaga.}

Berdasarkan hasil penelitian didapatkan responden dengan kategori sikap baik yakni sebanyak 34 responden (52,3\%). Hal ini dikarenakan oleh tingkat pengetahuan responden yang memiliki kategori pengetahuan yang baik yakni sebanyak 12 responden. Menurut teori Notoadmodjo (2012), yang menyatakan bahwa sikap baik atau positifnya seseorang dipengaruhi oleh pengetahuan yang baik, semakin baik pengetahuan yang dimiliki seseorang maka semakin baik pula sikap seseorang. Dalam penelitian yang dilakukan oleh Moudy (2020) hasil penelitiannya menunjukkan sebagian besar responden yang memiliki sikap yang baik memiliki pengetahuan yang baik juga. Peneliti berasumsi bahwa pengetahuan yang baik menentukan seseorang dalam bersikap positif terhadap suatu hal.

Adapun responden yang tidak memiliki pengetahuan yang baik tetapi dalam kategori sikap baik yakni sebanyak 22 responden. Hal ini dikarenakan adanya peraturanperaturan yang mengharuskan untuk bersikap positif terhadap pencegahan corona virus dan berdasarkan hasil wawancara yang dilakukan peneliti dengan setiap pemilik rumah makan didapatkan bahwa mengingat adanya aturan dari pemerintah tentang kewajiban menjalankan protokol kesehatan untuk pencegahan corona virus maka setiap rumah makan diberlakukan aturan kepada para pelayan rumah makan bahwa mereka harus mengantisipasi diri mereka, menjaga kesehatan, kebersihan dan daya tahan tubuh agar selalu sehat.

Menurut teori Firda \& Haksama (2020), yang menyatakan bahwa sikap masyarakat yang baik akan dilaksanakan dengan konsisten bila ada aturan yang tegas dari pemangku kebijakan atau pemerintah. Hal ini sejalan dengan penelitian yang dilakukan oleh Utami (2020) dalam hasil penelitiannya terdapat responden yang tidak memiliki pengetahuan yang baik namun memiliki sikap yang baik dalam pencegahan corona virus dikarenakan adanya aturan-aturan yang berlaku untuk pencegahan corona virus. Peneliti berasumsi bahwa dengan adanya aturan-aturan yang tegas tentang penceghan corona virus akan mendorong seseorang untuk bersikap baik dalam pencegahan corona virus.

Berdasarkan hasil penelitian ini juga didapatkan responden dengan kategori sikap cukup yakni sebanyak 29 responden (44,6\%). Hal ini dikarenakan oleh tingkat pengetahuan responden yang tidak memiliki kategori pengetahuan yang baik. Menurut teori Hakim (2012), yang menyatakan bahwa sikap sebagai kecenderungan afektif suka atau tidak suka pada suatu objek, semakin tidak baik pengetahuan seseorang terhadap suatu hal maka semakin terbatas dan tidak sepenuhnya seseorang dalam menyikapi hal tersebut. Hal ini sejalan dengan penelitian yang dilakukan oleh Gannika (2020) dalam hasil penelitiannya menunjukkan adanya hubungan tingkat pengetahuan dengan sikap pencegahan corona virus. Peneliti berasumsi bahwa pengetahuan merupakan dasar seseorang dalam menyikapi suatu hal yang diketahui dan dipahami, sikap yang positif dapat dibentuk oleh komponen kognitif.

Berdasarkan hasil penelitian ini juga didapatkan responden dengan kategori sikap kurang yakni sebanyak 2 responden $(3,1 \%)$. Hal ini dikarenakan oleh tingkat pengetahuan responden tidak memiliki kategori pengetahuan yang baik selain itu dapat dilihat juga berdasarkan hasil pengisian kuisioner responden sangat tidak setuju dengan adanya pernyataan untuk berhati-hati dengan corona virus, dalam mengantisipasi dan menjaga 
kesehatan dilakukan tidak efektif dan berdasarkan hasil wawancara yang dilakukan peneliti didapatkan responden mengatakan bahwa responden belum meyakini tentang kebenaran adanya corona virus, responden menganggap corona virus tidak ada. Keyakinan dan kepercayaan seseorang terhadap suatu hal dapat memberikn pengaruh seseorang dalam bersikap baik atau buruk.

Menurut teori Suryati (2015), yang menyatakan bahwa keyakinan dan kepercayaan seseorang akan menentukan dirinya dalam bersikap. Ketidakyakinan dan ketidakpercyaan seseorang terhadap suatu hal akan mendorong seseorang untuk tidak bersikap baik terhadap hal yang tidak diyakini atau dipercayai. Hal ini sejalan dengan penelitian yang dilakukan oleh Mudawaroch (2020) dalam hasil penelitiannya menunjukkan terdapat beberapa sikap responden yang kurang baik rata-rata responden yang tidak percaya dan tidak meyakini dengan adanya corona virus. Peneliti berasumsi bahwa keyakinan, kepercayaan dan emosional seseorang terhadap suatu hal atau objek dapat menentukan baik buruknya seseorang dalam bersikap.

\section{b. Perilaku Pelayan Rumah Makan Dalam Pencegahan Covid-19 di Kecamatan Telaga.}

Berdasarkan hasil penelitian didapatkan responden dengan kategori perilaku cukup yakni sebanyak 34 responden (52,3\%). Responden yang memiliki tingkat pengetahuan yang baik sebanyak 7 responden dan sebagian besar responden juga memiliki tingkat kategori sikap yang baik. Menurut teori Notoadmodjo (2012), yang menyatakan bahwa tingkat pengetahuan dapat menjadikan seseorang memiliki kesadaran sehingga seseorang akan berperilaku sesuai pengetahuan yang dimiliki, tingkat pengetahuan seseorang mempengaruhi tindakan seseorang dalam menjalankan suatu keputusan atau tindakan yang akan dilakukan. Menurut teori Siltrakool (2012), yang meyatakan bahwa sikap merupakan suatu kecenderungan seseorang untuk bertindak dimana tindakan yang dilakukan seseorang sebagai reaksi yang menggambarkan pengetahuan dan sikap yang dimilikinya. Hal ini sejalan dengan penelitian yang dilakukan oleh Lubis (2021) dalam hasil penelitiannya menunjukkan adanya hubungan antara tingkat pengetahuan, sikap corona virus dengan perilaku pencegahan corona virus. Peneliti berasumsi bahwa pengetahuan dan sikap yang tidak baik akan berdampak pada perilaku atau tindakan yang akan dilakukan.

Adapun responden yang tidak memiliki pengetahuan dan sikap yang baik tetapi dalam kategori perilaku yang cukup baik. Hal ini dikarenakan tersedianya sarana dan prasarana kesehatan, berdasarkan hasil wawancara yang dilakukan peneliti dengan setiap pemilik rumah makan didapatkan pemilik rumah makan menyatakan bahwa dalam bekerja pemilik rumah makan menyediakan sarana dan prasarana kesehatan seperti masker, hand sanitizer dan alat pelindung diri lainnya. Menurut teori Notoadmodjo (2014), yang menyatakan bahwa fasilitas-fasilitas atau sarana dan prasarana kesehatan merupakan faktor pendukung yang merupakan kelompok referensi dari perilaku masyarakat. Hal ini sejalan dengan penelitian yang dilakukan oleh Herawati (2021) dalam hasil penelitiannya menunjukkan bahwa ada hubungan yang bermakna antara ketersediaan sarana dan prasarana kesehatan dengan perilaku pencegahan corona virus. Peneliti berasumsi bahwa sarana dan prasarana merupakan salah satu hal yang bisa memenuhi tingkat keberhasilan dalam perilaku pencegahan corona virus.

614 AKSARA: Jurnal Ilmu Pendidikan Nonformal 
Berdasarkan hasil penelitian ini juga didapatkan responden dengan kategori perilaku kurang yakni sebanyak 22 responden $(33,8 \%)$. Hal ini dikarenakan masingmasing responden memiliki tingkat pengetahuan dan sikap dalam kategori kurang. Menurut teori Prihantana (2016), yang menyatakan bahwa pengetahuan memiliki kaitan erat dengan tindakan yang akan dilakukan. Faktor-faktor yang mempengaruhi tindakan atau perilaku seseorang tergantung pada pengetahuan dan juga persepsi atau sikap, semakin rendah pengetahuan dan persepsi seseorang maka berpengaruh pada tindakan dan perilaku yang akan dilakukannya (Sinuraya, 2018). Dalam penelitian yang dilakukan oleh Sari (2020) pada penelitiannya menunjukkan bahwa pengetahuan dan sikap memberikan pengaruh terhadap perilaku responden. Peneliti berasumsi bahwa semakin rendah pengetahuan dan sikap seseorang semakin kurang juga tindakan seseorang akan suatu hal yang tidak diketahuinya.

\section{KESIMPULAN}

Pengetahuan pelayan rumah makan dalam pencegahan Covid-19 di Kecamatan Telaga yaitu sebanyak 27 responden $(41,5 \%)$ dalam kategori kurang, 13 responden $(20 \%)$ memiliki pengetahuan baik, 25 responden $(38,5 \%)$ cukup baik.

Sikap pelayan rumah makan dalam pencegahan Covid di Kecamatan Telaga yaitu sebanyak 34 responden $(52,3 \%)$ sudah dalam kategori baik, 29 responden $(44,6 \%)$ cukup dan 2 responden $(3,1 \%)$ kurang. Perilaku pelayan rumah makan dalam pencegahan Covid-19 di Kecamatan Telaga yaitu sebanyak 34 responden $(52,3 \%)$ dalam kategori cukup baik, 9 responden $(13,8 \%)$ baik dan 22 responden $(33,8 \%)$ kurang baik.

\section{DAFTAR PUSTAKA}

Achmadi, U (2013). Kesehatan Masyarakat Teori dan Aplikasi. Jakarta:

Rajawali Pers.

Amelia, D.S (2020). Kesiapan Rumah Makan di Era New Normal. Jurnal Ilmu Kesehatan Masyarakat, 216-221.

Arikunto (2006). Prosedur Penelitian Suatu Pendekatan Praktek. Jakarta: Rineka Cipta.

Azwar, S (2013). Sikap Manusia. Teori dan Pengukurannya Edisi 2. Yogyakarta: Pustaka Belajar.

BPS (2020). Telaga Dalam Angka 2020, In Figures. Statistics of Gorontalo Regency. Gorontalo: Badan Pusat Statistik Kabupaten Gorontalo.

Budiharto (2013). Pengantar Ilmu Perilaku Kesehatan dan Pendidikan Kesehatan. Jakarta: Buku Kedokteran EGC.

Budiman \& Riyanto (2013). Kapita Selekta Kuisioner Pengetahuan dan Sikap Dalam Penelitian Kesehatan. Jakarta: Salemba Medika.

CDC (2020). Novel Coronavirus Pneumonia Emergency Response Epidemiology . China: Center Disease Control. 
Chen, Q (2020). Buku Panduan Pencegahan Coronavirus 101 Tips Berbasis Sains Yang Dapat Menyelamatkan Hidup Anda. China: Wuhan University.

Damiati (2017). Perilaku Konsumen. Depok: Rajawali Pers.

Dawei, W (2020). Clinical Characteristics of Patients with 2019 Novel Coronavirus (2019 NCoV). Retrieved from https://jamanet.work.com/journals/ja ma/fullarticle/2761044

Dinas Kesehatan Kabupaten Gorontalo (2021). Laporan Data Kasus Corona Virus Wilayah Kabupaten. Gorontalo: Dinas Kesehatan Kabupaten Gorontalo.

Dinas Kesehatan Provinsi Gorontalo (2021). Gorontalo Tanggap Darurat Covid19. Gorontalo: Dinas Kesehatan Provinsi Gorontalo.

Donsu, J.D.T (2017). Psikologi Keperawatan. Yogyakarta: Pustaka Baru Press.

Fahmi (2012). Manajemen Penyakit Berbasis Wilayah. Jakarta: PT. Rajagrafindo Persada.

Fiorillo, L (2020). Data Terbaru Sebuah Permukaan Terbaru Untuk Pengaturan Permukaan Benda. Jurnal Internasional Penelitian Lingkungan dan Kesehatan Masyarakat.

Firda, A \& Haksama, S (2020). Building Health System Resilience During Covid19 Crisis. Jurnal Administrasi Kesehatan Indonesia.

Gannika, L (2020). Tingkat Pengetahuan dan Perilaku Pencegahan Coronavirus Disease 2019 Pada Masyarakat Sulawesi Utara. Jurnal Keperawatan Vol 16 No.2, Hal. 83-89.

Habibi, A (2020). Normal Baru Pasca Covid-19. Retrieved from Normal Baru Pasca Covid-19: melalui:http://journal.uinjkt.ac.id

Hakim, L (2012). Internalisasi Nilai-nilai Dalam Pembentukan Sikap dan Perilaku. Jurnal Pendidikan. Tasikmalaya.

Herawati, C (2021). Faktor Determinan Perilaku Dalam Upaya Pencegahan dan Penanggulangan Covid-19. Jurnal Kesehatan Masyarakat Indonesia. Vol, 16 No.1 Hal 52-59.

Hidayat, A (2014). Metode Penelitian Keperawatan dan Teknik Analisa Data. Jakarta: Salemba Medika.

Indrawan, R (2014). Metodologi Penelitian Kualitatif, Kuantitatif dan Campuran. Surabaya: Refika Aditama.

Isbaniah, F (2020). Pedoman Pencegahan dan Pengendalian Coronavirus Disease (Covid-19). Jakarta Selatan: Direktorat Jenderal Pencegahan dan Pengendalian Penyakit Kementerian Kesehatan Republik Indonesia.

AKSARA: Jurnal Ilmu Pendidikan Nonformal 
Keliat, B., dkk (2020). Dukungan Kesehatan Jiwa dan Psikososial Covid-19. Bogor: Ilmu Pendidikan Keperawatan Jiwa Indonesia.

KEMENKES RI (2020). Keputusan Menteri Kesehatan Republik Indonesia Nomor HK.01.07/MENKES/382/2020. Tentang Protokol Kesehatan Di Tempat dan Fasilitas Umum .

(2020). Pedoman Pencegahan dan Pengendalian Coronavirus Disease (Covid-19). Jakarta Selatan : Kementerian Kesehatan Republik Indonesia.

(2021). Situasi Terkini Perkembangan Coronavirus Disease (Covid-19). Retrieved from Media Informasi Resmi Terkini Penyakit Infeksi Emerging: http://covid19.kemkes.go.id diakses pada tanggal 21 Maret 2021.

Kholid, A (2015). Promosi Kesehatan dengan Pendekatan Teori Perilaku, Media, dan Aplikasi. Jakarta: Rajawali Pers.

Lubis, D.A.S (2021). Hubungan Tingkat Pengetahuan Dengan Sikap dan Perilaku Terhadap Pemcegahan Infeksi Covid-19 Pada Mahasiswa Semester 6 Fakultas Kedokteran Univeristas Sumatera Utara. Skripsi Fakultas Kedokteran Pendidikan Dokter.

Mansuri, dkk (2020). Estimating the Public Response to Mitigation Measures and Selfperceived Behaviours Towards the Covid-19 Pandemic. Journal of Taibah University Medical Sciences.

Maulana, H (2007). Promosi Kesehatan. Jakarta: Penerbit Buku Kedokteran EGC.

Mona, N (2020). Konsep Isolasi Dalam Jaringan Sosial Untuk Meminimalisir Efek Contagious (Kasus Penyebaran Virus Corona Di Indonesia). Jurnal Sosial Humaniora Terapan Vol.2 No.2.

Moudy, J (2020). Pengetahuan terkait Usaha Pencegahan Coronavirus Disease (Covid-19). Higeia Journal of Public Health Research and Development, 333346.

Mubarak, W (2011). Promosi Kesehatan. Yogyakarta: Graha Ilmu.

Mudawaroch, R.E (2020). Pengaruh Pengetahuan dan Sikap Terhadap Perilaku Mahasiswa dalam Menghadapi Virus Corona. Seminar Nasional \& Call For Paper Hubisintek 2020 (257-263). Purworejo: Program Studi Peternakan Fakultas Pertanian Universitas Muhammadiyah Purworejo.

Nasrullah, D (2014). Etika dan Hukum Keperawatan untuk Mahasiswa dan Praktisi Keperawatan. Jakarta: TIM. 
Notoadmodjo, S (2007). Promosi Kesehatan dan Ilmu Perilaku. Jakarta: Rineka Cipta.

(2012). Metodologi Penelitian Kesehatan. Jakarta: Rineka

Cipta. (2014). Ilmu Perilaku Kesehatan. Jakarta: Rineka Cipta.

Novita, dkk (2014). Tingkat Pengetahuan Tentang TB Paru Mempengaruhi Penggunaan Masker Di Ruang Paru Rumkital Surabaya. Jurnal Ilmiah Kesehatan. Vol 7. No.12 Surabaya: Stikes Hang Tuah.

Nursalam (2011). Konsep dan Penerapan Ilmu Keperawatan. Jakarta: Salemba Medika.

Salemba Medika.

(2015). Metode Penelitian Ilmu Keperawatan. Jakarta Selatan:

Pennington, T (2020). Panduan Kesiapsiagaan Hadapi Virus Corona. Jakarta: PT. Elex Media Komputindo kelompok PT Gramedia Jakarta.

Prihantana (2016). Hubungan Pengetahuan Dengan Tingkat Kepatuhan Pengobatan Pada Pasien Tuberkulosis Di RSUD Dr. Soehadi Prijonegoro Sragen. Jurnal Farmasi Sains Dan Praktis. Vol. 2, No.1

Prihati, D.R (2020). Analisis Pengetahuan Dan Perilaku Masyarakat Di Kelurahan Baru Kotawaringin Barat Tentang Covid-19. Malahayati Nursing Journal. Vol 2. No.4, Hal. 780-790.

Purnamasari, I (2020). Tingkat Pengetahuan Dan Perilaku Masyarakat Kabupaten Wonosobo Tentang Covid-19. Jurnal Ilmiah Kesehatan. Hal. 33-42

Sari, D.P (2020). Hubungan Antara Pengetahuan Masyarakat Dengan Kepatuhan Penggunaan Masker Sebagai Upaya Pencegahan Penyait Covid-19 Di Ngronggah. Jurnal Ilmiah Rekam Medis dan Informatika Kesehatan. Vol, 10 No. 1 Hal. 52-55.

Sarwono, S \& Meinarno (2011). Psikologi Sosial. Jakarta: Salemba Humanika. Saryono (2009). Metodologi Penelitian Kesehatan. Yogyakarta : Nuha Medika.

Setiawaty, V (2013). Pedoman Pengambilan Spesimen dan Pemeriksaan Laboratorium. Jakarta: Kementerian Kesehatan Republik Indonesia.

Sharrif , F.O (2021). Gambaran Penegtahuan, Sikap dan Perilaku Dokter PTT Terhadap Pandemi Covid-19 Di Puskesmas Kabupaten Banyuasin. Malahayati Health Student Journal. Vol, 1 No.2 hal 113-121. 
Siltrakool, B (2012) Assessment of Community Pharmacists Knowledge, Attitude and Practice Regarding Non-Prescription Antimicrobial Use and Resistance in Thailand. PhD Thesis. University of Hertfordshire.

Sinuraya (2018). Tingkat Kepatuhan Pengobatan Pasien Hipertensi di Fasilitas Kesehatan Tingkat Pertama di Kota Bandung. Jurnal Farmasi Klinik Indonesia Vol 7. No.2, Sumedang: Universitas Padjajaran.

Sugiyono (2011). Metode Penelitian Kuantitatif, Kualitatif, dan R\&D. Bandung: Alfabeta.

(2017). Metode Penelitian Kuantitatif. Bandung: Alfabeta.

Sujarwo, R (2012). Faktor-faktor Yang Mempengaruhi Pengetahuan Rendah. Jurnal Universitas Airlangga.

Sukesih (2021). Tingkat Pendidika dan Pengathuan Dengan Perilaku Upaya Pencegahan Covid-19 Pada Masyarakat. Jurnal Ilmu Kesehatan Hal. 290-296.

Suryati, L (2015). Hubungan Pengetahuan Dan Sikap Ibu Hamil Dengan Pemberian Imunisasi Tetanus Toksoid Di Wilayah Kerja Puskesmas Maga Kecamatan Lembah Sorik Merapi Kabupaten Mandailing. Skripsi. Medan: Fakultas Kesehatan Masyarakat.

Susilo, A (2020). Buku Pedoman Pencegahan dan Pengendalian Coronavirus Disease (Covid-19). Jakarta Selatan: Direktorat Surveilans dan Karantina Kesehatan Kementerian Kesehatan Republik Indonesia.

Taufik, T \& Ayuningtyas (2020). Dampak Pandemi Covid-19 Terhadap Bisnis dan Eksistensi Platform Online. Retrieved from Pengembang Wiraswasta: http://ejurnal.stieipwija.ac.id

Triwibowo, C (2015). Pengantar Dasar Ilmu Kesehatan Masyarakat. Yogyakarta: Nuha Medika.

Utami, R.A (2020). Pengetahuan, Sikap, dan Keterampilan Masyarakat Dalam Pencegahan Covid-19 Di Provinsi DKI Jakarta. Jurnal Kesehatan Holistic, 68-77.

Wahyudi (2020). Kebijakan Pemberlakuan Lockdown Sebagai Antisipasi Penyebaran Corona Virus Covid-19. Jurnal Sosial dan Budaya Syar-i. Volume 7 Nomor 7 (2020), 639-649.

Wawan, A. \& Dewi (2010). Teori dan Pengukuran Pengetahuan, Sikap dan Perilaku Manusia. Yogyakarta: Nuha Medika.

Widiyani, R (2020). Latar Belakang Virus Corona. Retrieved from Detik News: https://new.detik.com/berita/d4943950 
Yanti, N.P.E.D (2020). Gambaran Pengetahuan Masyarakat Tentang Covid-19 dan Perilaku Masyarakat Di Masa Pandemi Covid-19. Jurnal Keperawatan Jiwa Universitas Muhammadiyah Semarang, 491-504.

Zhou, W (2020). Buku Panduan Pencegaham Coronavirus. China: Wuhan University. 